J. Akademika Kim. 5(2): 98-102 May 2016

ISSN 2302-6030 (p), 2477-5185 (e)

\title{
UJI DAYA HAMBAT EKSTRAK BAWANG HUTAN (Eleutherine palmifolia (L.) merr) dari MATANTIMALI TERHADAP PERTUMBUHANJAMUR Candida albicans
}

\section{The Inhibitory Test of Extract of Forest Onion (Eleutherinepalmifolia(L.) merr) from Matantimali on Growth of Fungus Candida albicans}

\author{
*Siti Nuryanti, Minarni R. Jura, dan Sri Wahyuni \\ Pendidikan Kimia/FKIP - Universitas Tadulako, Palu - Indonesia 94118 \\ Received 21 March 2016, Revised 25 April 2016, Accepted 23 May 2016
}

\begin{abstract}
Forest onion is a plant that is widely used as a traditional medicine and natural antioxidants. The aim of this study is to determine the extract of the forest onion that can inhibit the growth of the fungus candida albicans and to compare the inhibitory of extract of the forest onion (eleutherine palmifolia (L.) merr) by using different solvents, namely ethanol and distilled water which is carried out by the method of pitting. Suspension of the fungus candida albicanswas obtained from Clinicaly Laboratory Palu, Central Sulawesi. The results of research obtained that the inhibition of extract of the forest onionon growth of the funguscandida albicanswith ethanol was greater than with distilled water, the percentace was $65.44 \%$ and $54.78 \%$ for each solvents. It can be concluded that extract of the forest onion has the inhibitory on the growth of the fungus candida albicans.
\end{abstract}

Keywords: Forest onion, anti-fungus, candida albicans, Extraction.

\section{Pendahuluan}

Infeksi merupakan penyakit yang mudah ditemukan di daerah tropis seperti Indonesia. Penyebab penyakit infeksi diantaranya adalah infeksi karena jamur. Jamur merupakan suatu mikroorganisme eukariotik yang mempunyai ciri-ciri spesifik yaitu mempunyai inti sel, memproduksi spora, tidak mempunyai klorofil, dapat berkembang biak secara seksual dan aseksual (Setyowati, dkk., 2013). Infeksi jamur sistemik yang tak tertangani bisa berakibat fatal, menyebabkan kecacatan bahkan kematian. Salah satu spesies jamur yang sering menyebabkan infeksi adalah candida albicans(Widiarta, 2008).

Infeksi yang disebabkan oleh jamur candida albicans ini dikenal dengan candidiasis.Obat tropikal yang selama ini digunakan untuk mengobati candidiasis meliputi nistatin, klotrimazol, mikonazol, dan azol-azol lainnya. Namun penggunaan obat-obat anti jamur tersebut memiliki keterbatasan, seperti efek samping yang berat, spektrum anti jamur yang

*Correspondence:

Siti Nuryanti

Program Studi Pendidikan Kimia, Fakultas Keguruan dan Ilmu Pendidikan, Universitas Tadulako

email: sitinoer_untad@yahoo.com

Published by Universitas Tadulako 2016

sempit, penetrasi yang buruk pada jaringan tertentu, dan munculnya jamur yang resisten (Setyowati, dkk., 2013).Oleh karena itu, pemanfaatan tanaman sebagai bahan obat tradisional mulai dikembangkan. Keuntungan menggunakan tanaman berkhasiat obat adalah bahan bakunya mudah didapat, harganya murah, dapat diracik sendiri serta menunjukkan efek samping yang relatif rendah dibandingkan dengan obat-obat modern yang beredar dipasaran, sehingga pemakaian bahan tradisional sudah mulai berkembang(Mekhanzie, 2012)

Salah satu alternatif tanaman yang digunakan sebagai obat adalah bawang hutan. Bawang hutan mengandung senyawa metabolit sekunder yaitu alkaloid, flavonoid, saponin, tannin, triterpenoid dan steroid (Septianingsih, 2013).Pada umbi bawang hutan terkandung senyawa metabolit sekunder yakni alkaloid, glikosida, flavanoid, steroid dan tanin yang merupakan sumber biofarmaka yang berpotensial untuk dikembangkan sebagai tanaman obat modern dalam kehidupan manusia (Sofyan, 2011). Fitokimia inilah yang memiliki peran dalam menjaga kesehatan tubuh (Wuryanti \& Murnah, 2009). 
Bawang hutan merupakan salah satu tanaman yang berkhasiat obat. Bulbus tanaman bawang hutan dimanfaatkan sebagai obat kanker payudara, selain itu juga dapat digunakan untuk mengatasi gangguan jantung, meningkatkan daya tahan tubuh, sebagai antiinflamasi, antitumor serta dapat menghentikan pendarahan (Kuntorini, 2013). Setyowati, dkk., (2013) mengatakan bahwa senyawa antijamur yang berasal dari tanaman sebagian besar diketahui merupakan metabolit sekunder tanaman, terutama golongan fenolik dan terpen dalam minyak atsiri. Selain fenolik, flavonoid, dan triterpenoid.Dalam proses ekstraksi suatu bahan tanaman, banyak faktor yang dapat mempengaruhi kandungan senyawa hasil ekstraksi diantaranya yaitu jenis pelarut, konsentrasi pelarut, metode ekstraksi dan suhu yang digunakan untuk ekstraksi (Rima, dkk., 2014). Jenis pelarut pengekstraksi juga mempengaruhi jumlah senyawa aktif yang terkandung dalam ekstrak, sesuai konsep like dissolve like, dimana senyawa yang bersifat polar akan larut dalam pelarut polar dan senyawa yang bersifat non polar akan larut dalam pelarut non polar (Lusiana, dkk., 2014). Tulisan ini mendeskripsikan penelitian tentang penentuan ekstrak bawang hutan (eleutherine palmifolia (L.) merr) yang dapat menghambat pertumbuhan jamur candida albicans dan membandingkan daya hambat ekstrak bawang hutan terhadap jamur dengan menggunakan pelarut yang berbeda yakni pelarut etanol dan aquades.

\section{Metode}

\section{Alat dan Bahan}

Alat yang digunakan yaitu neraca digital (Kern), gelas ukur, gelas kimia, jarum ose, vortex, penangas listrik, pinset, Erlenmeyer, shaker orbital (Gerhardt), pipet tetes, autoklaf (Manitowoc), inkubator, cawan petri, blender, spatula, cetakan berbentuk bulat, mistar, jangka sorong, labu ukur.

Bahan yang digunakan yaitu etanol (Merck), aluminium foil, jamur candida albicans, aquades, media NA (Nutrient Agar), media NB (Nutrient Broth), larutan standar MC. Farland, tissue, serbuk bawang hutan, plastik tahan panas.

\section{Prosedur penelitian \\ Preparasi sampel}

Bawang hutan yang bersih dipotong kecil-
kecil.Selanjutnya dikering anginkan selama 7 hari (1 minggu). Setelah kering, dihaluskan dengan menggunakan blender sampai halus.

\section{Pembuatan Ekstrak}

Ditimbang 100 gram serbuk bawang hutan, dimasukkan kedalam dua erlenmeyer yang masing-masing erlenmeyer berisi 50 gram.Setelah itu, sebanyak $150 \mathrm{~mL}$ aquadesditambahkan pada erlenmeyer satu dan $150 \mathrm{~mL}$ etanol kedalam erlenmeyer dua. Kemudian kedua erlenmeyer tersebut ditutup dengan menggunakan aluminium foil dan direndam selama 2 x 24 jam sambil dikocok menggunakan shaker. Setelah itu ekstrak disaring menggunakan kertas saring dan filtrat yang didapatkan digunakan dalam pengujian uji daya hambat jamur.

\section{Pembuatan Media NA (Nutrient Agar)}

Sebanyak 7 gram nutrient agar ditimbang kemudian ditambahkan aquades sebanyak $250 \mathrm{~mL}$ dan dipanaskan sambil diaduk sampai nutrien agar larut secara sempurna dan campuran menjadi jernih.Setelah itu media yang telah dibuat dituangkan kedalam empat cawan petri steril dan masing-masing cawan petri berisi $10 \mathrm{~mL}$ sebagai layer bawah. Kemudian cawan petri dibungkus dengan plastik tahan panas lalu disterilisasi selama 15 menit dengan menggunakan autoklaf pada suhu $12 \mathrm{oC}$ dan tekanan $1 \mathrm{~atm}$ sehingga menghasilkan media yang telah steril.

\section{Pembuatan Media NB (Nutrient Broth)}

Sebanyak 3,25 gram nutrient broth ditimbang kemudian ditambahkan aquades sebanyak $250 \mathrm{~mL}$. Setelah itu diambil media nutrient broth yang telah dibuat sebanyak 30 mL lalu ditambahkan dengan jamur candida albicans sebanyak 5 ose yang disetarakan dengan kekeruhan larutan standar MC. Farland, lalu dikocok dan divortex agar tercampur secara merata. Setelah itu diinkubasi selama 24 jam pada suhu $37 \mathrm{oC}$ sehingga menghasilkan media yang agak bening.

\section{Uji Daya Hambat Ekstrak Bawang Hutan}

Sebanyak 90 mL media NA dicampurkan dengan campuran (NB + jamur).Kemudian dituangkan ke dalam empat cawan yang telah berisi NA dan masing-masing cawan sebanyak $30 \mathrm{~mL}$ sebagai layer atas.Setelah itu campuran tersebut didinginkan hingga campuran menjadi 
padat.Setelah media padat, dibuat lubang/ sumuran pada tengah cawan dan diangkat bagian tengahnya dengan menggunakan pinset/spatula sehingga terbentuk sumuran. Kemudian ditambahkan ekstrak bawang hutan yang telah diekstraksi dengan pelarut etanol dan pelarut aquades pada lubang sumuran yang telah dibuat sebanyak $1 \mathrm{~mL}$ dan selanjutnya diinkubasi selama 24 jam pada suhu $37^{\circ} \mathrm{C}$.

\section{Hasil dan Pembahasan}

Penelitian mengenai uji aktivitas anti jamur candida albicans dari ekstrak bawang hutan (Eleutherine palmifolia (L.) merr) yang diperoleh dari Desa Matantimali yang dilakukan dengan cara mengekstrak dan menguji daya hambat jamur dengan menggunakan metode sumuran dengan cara membuat lubang pada agar padat yang telah diinokulasi dengan jamur. Kemudian lubang tersebut diinjeksikan dengan ekstrak bawang hutan.Pengukuran daya hambat dari hasil uji aktivitas anti jamur ekstrak bawang hutan terhadap pertumbuhan jamur candida albicans pada daerah bening atau jernih disekitar sumuran. Hasil menunjukkan koloni jamur yang diberi ekstrak bawang hutan memiliki persen daya hambat jamur lebih besar dibandingkan dengan koloni pada kontrol negatif, seperti terlihat dalam Tabel 1

Tabel 1. Data daya hambat ekstrak bawang hutan Eleutherine palmifolia (L.) merr) terhadap jamur Candida albicans

\begin{tabular}{|llc|}
\hline NO & Ekstrak Bawang Hutan Dalam Pelarut & Daya Hambat Jamur (\%) \\
\hline 1. & Aquades & 54,78 \\
2. & Etanol & 65,44 \\
3. & Aquades (Kontrol negatif) & 6,98 \\
4. & Eranol (Kontrol negatif) & 0 \\
\hline
\end{tabular}

Penelitian yang dilakukan mengenai daya hambat pertumbuhan jamur menggunakan sampel ekstrak umbi bawang hutan (eleutherine palmifolia (L.) merr) yang berasal dari daerah Matantimali dan jamur candida albicans yang digunakan pada penelitian ini diperoleh dari Laboratorium Kesehatan Palu Sulawesi Tengah.

Identifikasi Candida albicans ditanam pada media yang diinkubasi akan terbentuk koloni lunak berwarna krem, yang mempunyai bau khas seperti ragi (Puspawati, 2007).
Berdasarkan pengamatan dan pengukuran yang telah dilakukan diperoleh hasil masing-masing luas daerah yang ditumbuhi jamur terlihat seperti terlihat pada Gambar 1

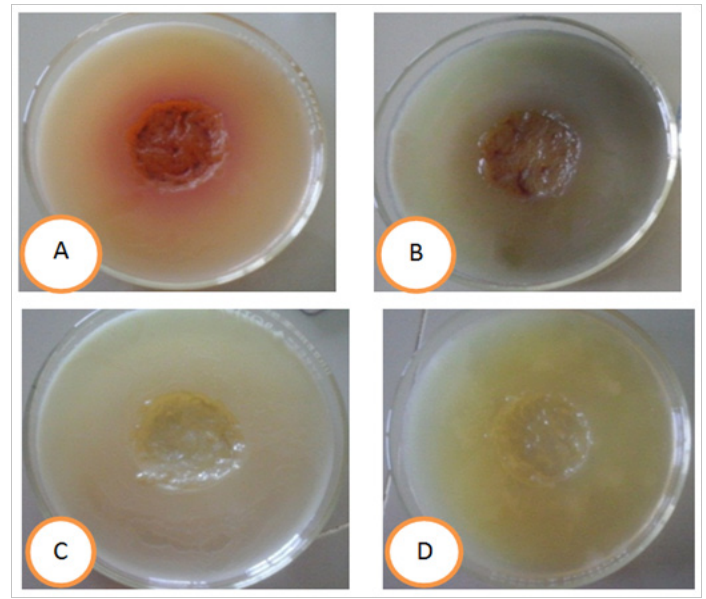

Gambar 1. Daya hambat pertumbuhan jamur Candida Albicans (A) ekstrak bawang hutan dengan pelarut etanol, (B) ekstrak bawang hutan dengan pelarut aquades, (C) larutan etanol (kontrol), (D) pelarut aquades (kontrol)

Berdasarkan Gambar 1 dapat terlihat bahwa pada ekstrak bawang hutan dengan menggunakan pelarut etanol memperoleh luas daerah yang tidak ditumbuhi jamur lebih besar dibandingkan dengan ekstrak bawang hutan yang menggunakan pelarut aquades dikarenakan pelarut etanol ini dapat mengesktrak hampir semua senyawa bahan alam yang terdapat pada tumbuhan. Hal ini dapat dilihat pada Gambar 1, dimana pada gambar terlihat bahwa ekstrak bawang hutan dengan pelarut etanol $70 \%$ ditumbuhi jamur pada bagian pinggiran media, akan tetapi pada ekstrak bawang hutan dengan menggunakan pelarut aquades terlihat bahwa pinggiran media ditumbuhi jamur lebih banyak. Sedangkan pada kontrol dengan pelarut aquades sebagian besar ditumbuhi jamur, bahkan pada pelarut etanol 70\% hampir semua media dan sumuran ditumbuhi jamur. Sehingga dapat dikatakan bahwa ekstrak bawang hutan (eleutherine palmifolia (L.) merr) mempunyai fungsi sebagai antijamur candida albicans. Mekanisme penghambatan pertumbuhan jamur oleh ekstrak bawang hutan ini diduga berasal dari kandungan senyawa fitokimia yang dikandung oleh tanaman tersebut.

Diana, dkk (2014) mengungkapkan bahwa ekstrak bawang hutan (eleutherine palmifolia (L.) merr) memiliki aktivitas penghambatan 
pertumbuhan jamur. Hal ini dikarenakan oleh adanya senyawa metabolit sekunder dalam bawang hutan yang berpotensi sebagai antijamur.Derivat kuinon yang terkandung dalam umbi bawang hutan memiliki potensi sebagai antijamur(Chansukh, dkk., 2012). Senyawa yang berpotensi sebagai antijamur dalam ekstrak bawang hutan yaitu senyawa alkaloid, tanin, fenolik, dan flavonoid (Diana, dkk., 2014). Alkaloid dan flavonoid mempengaruhi komponen sel jamur dengan cara merusak membran sel dan mendenaturasi protein. Gugus flavonoiddapat bertindak sebagai antijamur karena mempunyai fenol yang dapatmendenaturasi protein dan dapat merusak membran sel yang bersifat irreversible(tidak dapat diperbaiki lagi) (Dewi, 2009). Semakin lipofilik suatuflavonoid semakin merusak membran mikroba (Cowan, 1999).

Flavonoid mempunyai berbagai keaktifan biologis antara lain mempunyai keaktifan sebagai obat, insektisida, antimikroba, anti virus, anti jamur, obat infeksi pada luka, mengurangi pembekuan darah dalam tubuh, mempercepat pembekuan darah di luar tubuh, antioksidan, anti tumor dan anti kanker (Robinson, 1995). Sedangkan tanin merusak dinding sel jamur yang terdiri atas lipid dan asam amino. Kerusakan membran sel dapat menyebabkan meningkatnya permeabilitas sel sehingga mengakibatkan kerusakan sel jamur. Tanin tergolong senyawa polifenol dengan karakteristiknya yang dapat membentuk senyawa kompleks dengan makromolekul lainnya(Jayanegara \& Sofyan, 2008). Senyawa tanin dapat mengganggu permeabilitas sel karena kemampuannya dapat mengkerutkan dinding sel atau membran sel. Pada dinding sel yang tidak selektif permeabel, penetrasi senyawasenyawa tersebut mudah menembus dinding sel yang akan menimbulkan terganggunya integritas dinding sel bakteri (Pambayun, dkk., 2007). Senyawa fenolik dapat mendenaturasi protein yaitu dengan cara merusak struktur tersier protein. Denaturasi pada protein enzim akan menyebabkan enzim tidak dapat bekerja sehingga mengganggu metabolisme dan proses penyerapan nutrisi oleh jamur (Diana, dkk., 2014).

\section{Kesimpulan}

Ekstrak bawang hutan memiliki daya hambat terhadap pertumbuhan jamur candida albicans. Hal ini dapat dilihat pada hasil persentase daya hambat jamur dari ekstrak bawang hutan dengan pelarut etanol $70 \%$ dan aquades yaitu beerturut-turut $65,44 \%$ dan $54,78 \%$.
Ekstrak bawang hutan dengan pelarut etanol mempunyai persentase daya hambat jamur lebih besar dibandingkan dengan ekstrak bawang hutan yang menggunakan pelarut aquades.Hal ini dikarenakan pelarut etanol dapat mengekstrak hampir semua senyawa bahan alam yang terdapat pada tumbuhan.

\section{Ucapan Terima Kasih}

Ucapan terima kasih penulis ucapkan kepada Laboran Laboratorium Pendidikan KIMIA FKIP dan Laboran Laboratorium Agroteknologi Fakultas Pertanian Universitas Tadulako dan semua pihak yang banyak membantu penulis dalam menyelesaikan penelitian ini.

\section{Referensi}

Chansukh, K., Charoensup, R., Palanuvej, C. \& Ruangrungsi, N. (2012). Antimicrobial activities of selected Thai medicinal plants bearing quinonoids. Research Journal of Pharmaceutical, Biological and Chemical Sciences, 5(2), 425-432.

Cowan, M. M. (1999). Plant product as antimicrobial agents. Clinical Microbiology Reviews, 12(4), 564-582.

Dewi, R. C. (2009). Uji aktivitas antijamur ekstrak buah pare belut (trichosanthes anguina l.). Universitas Sebelas Maret, Surakarta.

Diana, N., Khotimah, S. \& Mukarlina. (2014). Penghambatan pertumbuhan jamur fusarium oxysporum schlecht pada batang padi (oryza sativa L.) menggunakan ekstrak metanol umbi bawang hutan (eleutherina palmifolia merr). Jurnal Protobiont, 3(2), $15-22$.

Jayanegara \& Sofyan. (2008). Penentuan aktivitas biologis tanin beberapa hijauan secara in vitro menggunakan 'hohenheim gas test' dengan polietilen glikol sebagai determinan. 31(1), 44-52.

Kuntorini, E. M. (2013). Kemampuan antioksidan bulbus bawang dayak (eleutherine americana merr) pada umur berbeda. Universitas Lampung, Lampung.

Lusiana, A., Rice, O. D. \& Idha, K. (2014). Pengaruh jenis pelarut pengektraksi terhadap kadar sinensetin dalam ekstrak daun orthosiphon stamineus enth. E-Journal Planta Husada, 2(1), 1-4. 
Mekhanzie, M. (2012). Pengaruh berbagai konsentrasi ekstrak daun jambu mete sebagai denture cleanser terhadap pertumbuhan candida albicans dengan waktu perendaman 15 menit. Universitas Jember, Jember.

Pambayun, R., Gardjito, M., Sudarmadji, S. \& Kuswanto, K. R. (2007). Kandungan fenol dan sifat antibakteri dari berbagai jenis ekstrak produk gambir (uncaria gambir roxb). Jurnal Farmasi Indonesia, 18(3), 1-6.

Puspawati, N. (2007). Uji aktivitas anti jamur ekstrak soxhletasi daun kaki kuda (centella asiatica, urb.) terhadap candida albicans ATCC 10231 dan candida albicans hasil isolasi penderita sariawan. Universitas Setia Budi, Surakarta.

Rima, S. Y., Elisa, I., Akhmad, N. K. \& Erna, S. P. (2014). Perbandingan metode ekstraksi dan variasi pelarut terhadap rendemen dan aktivitas antioksidan ekstrak kubis ungu (brassica oleracea 1. var. capitata f. rubra). Traditional Medicine Journal, 19(1), 43-48.

Septianingsih, S. F. (2013). Uji ekstrak aktivitas antioksidan dari bawang hutan (eleutherine palmifolia (L) merr). Universitas Tadulako, Palu.

Setyowati, H., H. Z. Hanifah \& Nugraheni, R. P. (2013). Krim kulit buah durian (durio zibethinus L) sebagai obat herbal pengobatan infeksi jamur candida albicans. Sekolah Tinggi Ilmu Farmasi Semarang, Semarang.

Sofyan, A. G. (2011). Formulasi sediaan gel antioksidan ekstrak etanol bawang sabrang (eleutherine palmifolia (l.) merr) berbasis $H P M C$. Universitas Sumatra Utara, Medan.

Widiarta, R. K. (2008). Uji banding efektivitas infus jintan hitam (nigella sativa) $100 \%$ dengan ketokonazol 2\% secara in vitro terhadap pertumbuhan candida albicans. Fakultas Kedokteran Universitas Diponegoro, Semarang.

Wuryanti \& Murnah. (2009). Uji ekstrak bawang bombay terhadap antibakteri gram negatif pseudomonas aeruginosa dengan metode difusi cakram. Jurnal Sains \& Matematika, 17(3), 151-158. 